\title{
Prognostic factors influencing the outcome in Pneumocystis carinii pneumonia in patients with AIDS
}

Patricia Fernandez, Antonio Torres, Jose M Miro, Carlos Vieigas, Jose Mallolas, Laura Zamora, Jose M Gatell, Maria E Valls, Raul Riquelme, Roberto Rodríguez-Roisin

\begin{abstract}
Background - Studies attempting to identify the prognostic factors that influence the outcome of Pneumocystis carinii pneumonia (PCP) in patients with AIDS using a multivariate analysis are few. In order to identify those prognostic factors amenable to medical intervention, univariate and multivariate analyses were performed on 102 patients with AIDS suffering a first episode of PCP.

Methods - One hundred and two consecutive patients with AIDS (51\% drug abusers, $45 \%$ homosexuals, and $4 \%$ with other HIV risk factors) admitted to our institution between 1986 and 1989 whose respiratory infection was diagnosed by bronchoalveolar lavage were studied prospectively.
\end{abstract}

Results - The overall mortality was $28 \%$, rising to $79 \%$ in those patients who required mechanical ventilation. According to univariate analysis the following variables were related to a poor prognosis: age $>35$ years; risk factor for HIV infection other than drug abuse; an AIDS diagnosis confirmed before 1988; $\mathrm{PaO}_{2}<8 \mathrm{kPa}$ at admission; severe acute respiratory failure on admission $\left(\mathrm{PaO}_{2} / \mathrm{FIO}_{2}\right.$ $<20 \mathrm{kPa}$ ); mechanical ventilation; antibiotic therapy for PCP other than trimethoprimsulphamethoxazole; multiple microbial pulmonary infection; serum lactate dehydrogenase (LDH) $>22.5 \mu \mathrm{kat} / \mathrm{l}$ on admission; serum albumin level $<30 \mathrm{~g} /$. Multivariate analysis showed that only mechanical ventilation was independently associated with a poor outcome.

Conclusions - The mortality of AIDS patients presenting with a first episode of PCP before 1990 was high (28\%). The main prognostic factor associated with poor outcome was the requirement for mechanical ventilation due to severe acute respiratory failure.

(Thorax 1995;50:668-671)

Keywords: Pneumocystis carinii pneumonia (PCP); AIDS; prognosis.

Reprint requests to Dr J M Miro.

Received 21 July 1994

Returned to author

3 November 1994

Revised version received 26 January 1995

Accepted for publication

6 March 1995
Pneumocystis carinii penumonia (PCP) is one of the most frequent causes of morbidity and mortality in patients with AIDS. This pulmonary complication occurs in approximately
$80 \%$ of those who do not receive primary prophylaxis. ${ }^{12}$ Mortality in AIDS patients with PCP ranges between $10 \%$ and $40 \%^{3-6}$ despite adequate antibiotic treatment with trimethoprim-sulphamethoxazole or pentamidine. Mortality increases from $50 \%$ to $100 \%$ in patients who develop acute respiratory failure requiring mechanical ventilation. ${ }^{7-11}$

Several studies have evaluated different clinical and physiological variables as indicators of the outcome of PCP in patients with AIDS. In a univariate analysis of prognosis, the severity of radiological abnormalities and an alveolar to arterial oxygen gradient $\left(\mathrm{A}-\mathrm{a} \mathrm{Po}_{2}\right)$ of $>4 \mathrm{kPa}$ on admission predicted a poor outcome. ${ }^{6}$ Other studies have identified other factors associated with mortality such as serum lactate dehydrogenase $(\mathrm{LDH})$ and albumin levels, ${ }^{34}$ the existence of leucocytosis and, more recently, the presence of bronchoalveolar lavage fluid neutrophilia. ${ }^{12}$ Studies of the prognosis of AIDS patients with PCP have generally used univariate statistical methods and only two reports ${ }^{313}$ have used a multivariate statistical method.

The aim of the present study was to assess the prognostic factors influencing the outcome of the first episode of PCP in patients with AIDS diagnosed before 1990 using both univariate and multivariate statistical methods, to identify better those subsets of population amenable to medical intervention.

\section{Methods}

PATIENTS

One hundred and two patients with HIV infection consecutively admitted to the Hospital Clinic of Barcelona with a first episode of PCP were studied. The study was conducted prospectively between January 1985 (when the first case of AIDS was diagnosed in our institution) and December 1989.

\section{DIAGNOSTIC CRITERIA}

The diagnosis of AIDS was confirmed according to the CDC definitions. ${ }^{14}$ The diagnosis of PCP was based upon the presence of characteristic cysts in Gomori's methenamine silver stain or the presence of trophozoites in a Giemsa stain from samples of bronchoalveolar lavage fluid. 
Table 1 Demographic and clinical characteristics of the 102 patients

\begin{tabular}{lc}
\hline & No. (\%) \\
\hline Demographics & \\
Mean (range) age (years) & $34(18-70)$ \\
Sex (M:F) & $95: 7$ \\
Risk factors & $51(51)$ \\
Drug abuse & $45(45)$ \\
Homosexuality & $4(4)$ \\
Other & \\
Years of diagnosis & $40(39)$ \\
1985-7 & $62(61)$ \\
1988-9 & \\
AIDS indicator event & $64(63)$ \\
PCP & $31(30)$ \\
Other & $7(7)$ \\
Kaposi's sarcoma & \\
Clinical data & \\
Symptoms & $99(97)$ \\
Fever & $96(94)$ \\
Cough & $18(18)$ \\
Chest pain & $44(43)$ \\
Dyspnoea & $54(53)$ \\
Weight loss & $21(2-90)$ \\
Mean (range) duration of symptoms (days) & \\
Lung examination & $36(35)$ \\
Normal & $66(65)$ \\
Crackles/rales & $9(9)$ \\
Chest radiographs & $98(28)$ \\
Normal & $63(62)$ \\
Localised infiltrates & $1(1)$ \\
Bilateral infiltrates & $19(19)$ \\
Cavitation/pneumothorax & $83(81)$ \\
Mechanical ventilation & \\
Yes & \\
No & \\
\hline & \\
& \\
\hline
\end{tabular}

\section{VARIABLES STUDIED AND DEFINITIONS}

In all patients the following variables were recorded: sex, age, risk factors for HIV infection, event indicator of AIDS, time since AIDS diagnosis, and the presence of the following clinical symptoms and their duration before admission: cough, haemoptysis, chest pain, dyspnoea, weight loss, and fever. Other analysed variables included auscultation of rales, antibiotic treatment for PCP, radiological appearance on admission (normal; unilateral or bilateral infiltrates; cavitation; pneumothorax), arterial blood gas tensions on admission, the need for mechanical ventilation and the following blood tests on admission: haematocrit (\%), level of haemoglobin $(\mathrm{g} / \mathrm{dl})$, leucocyte, lymphocyte and CD4 + counts (cells $\times 10^{9} / 1$ ), serum albumin $(\mathrm{g} / \mathrm{l})$, cholesterol $(\mathrm{mmol} / \mathrm{l})$ and serum lactate dehydrogenase $(\mathrm{LDH})(\mu \mathrm{kat} / \mathrm{l})$. Acute respiratory failure was diagnosed if the $\mathrm{PaO}_{2}$ was $<8 \mathrm{kPa}$ breathing room air. The $\mathrm{A}-\mathrm{a} \mathrm{Po}_{2}$ was calculated using the alveolar gas equation ${ }^{16}$ assuming the respiratory quotient $(R)$ to be $0 \cdot 8$. Severe acute respiratory failure was considered present if the patient had a $\mathrm{PaO}_{2} / \mathrm{FIO}_{2}<20 \mathrm{kPa}$.

In this study all HIV infected patients with clinical and radiological data suggesting PCP

Table 2 Laboratory characteristics of patients on admission to ICU

\begin{tabular}{|c|c|c|}
\hline & Mean (SD) & Reference values \\
\hline \multicolumn{3}{|l|}{ Arterial $\mathrm{Po}_{2}(\mathrm{kPa})$} \\
\hline Mean & 8.9 & \\
\hline Range & $5 \cdot 5-16$ & \\
\hline$<8$ & $40(39 \%)$ & \\
\hline Haemoglobin $(\mathrm{g} / \mathrm{l})$ & $107(24)$ & $120-160$ \\
\hline Leucocyte count $\left(10^{9} / 1\right)$ & $5.657(2 \cdot 832)$ & $4-10$ \\
\hline Lymphocyte count $\left(10^{9} / 1\right)$ & $0.659(0.449)$ & $1 \cdot 5-3$ \\
\hline $\begin{array}{l}\text { CD4 lymphocyte count }\left(10^{9} / 1\right) \\
<0.2 \times 10^{9} / 1\end{array}$ & $\begin{array}{c}0 \cdot 11 \quad(0 \cdot 09) \\
80 \%\end{array}$ & $0 \cdot 8-1 \cdot 2$ \\
\hline Serum albumin $(g / 1)$ & $31(7 \cdot 5)$ & $35-50$ \\
\hline Serum cholesterol $(\mathrm{mmol} / \mathrm{l})$ & $3.54 \quad(1.06)$ & $<6.20$ \\
\hline Serum LDH $(\mu \mathrm{kat} / \mathrm{l})$ & $15 \cdot 7 \quad(10.9)$ & $<7.5$ \\
\hline
\end{tabular}

$\mathrm{LDH}=$ lactate dehydrogenase. were treated presumptively. Bronchoscopy was usually performed during the first week in hospital. Antibiotic therapy included intravenous or oral trimethoprim-sulphamethoxazole (20$100 \mathrm{mg} / \mathrm{kg} /$ day respectively) or intravenous pentamidine $(4 \mathrm{mg} / \mathrm{kg} /$ day $)$ according to the decision of the attending physician. Corticosteroids were not routinely used before 1990 and were only given to some patients with severe acute respiratory failure who were admitted to the respiratory intensive care unit (RICU). Patients enrolled in the present study did not receive primary prophylaxis for PCP which was initiated in our institution from October 1989. ${ }^{17}$

For the purpose of this study only the mortality related to the PCP episode during the period in hospital (inhospital mortality) has been considered.

\section{STATISTICAL ANALYSIS}

In the univariate analysis the $\chi^{2}$ test and Fisher exact test were used when appropriate. The odds ratio, the $95 \%$ confidence intervals and their level of significance were calculated as previously described.$^{18} \mathrm{~A}$ relative risk of death of 1 was arbitrarily assigned to the lowest risk category within each variable studied. The multivariate analysis was performed using a stepwise logistic regression analysis as described by Cox ${ }^{19}$ and Lee. ${ }^{20}$ The logistic equation obtained allowed the calculation of probability for survival or mortality. The unconditional logistic regression was also applied in order to adjust to confounding factors in the case-control study as described by Breslow and $\mathrm{Day}^{21}$ and by Schlesselman. ${ }^{18}$ A stepforward approach was used with $0 \cdot 10$ as a limit for entering or removing terms. All variables were entered in the logistic regression as categoric variables with two categories: $-1=$ absent or normal, $1=$ present or abnormal.

\section{Results}

CHARACTERISTICS OF THE POPULATION STUDIED Of the 102 patients studied there were 95 men; the mean age of the group was 34 years (range 18-70). Risk factors for HIV were drug abuse in 51 patients $(51 \%)$, homosexuality in 45 (45\%) and other in six (6\%). Pneumocystis carinii pneumonia was the AIDS defining event in 64 cases, Kaposi's sarcoma in seven, and other opportunistic infections in the remaining 31.

Cough and fever were the most frequent symptoms ( $90 \%$ of patients). Dyspnoea and weight loss were present in almost $50 \%$ of cases (table 1). In 36 patients physical examination did not reveal abnormalities while crackles or rales were heard in the remaining patients.

Chest radiography on admission showed bilateral infiltrates in 63 cases, localised infiltrates in 28, and a normal radiograph in nine. Mean $\mathrm{PaO}_{2}$ breathing room air at admission was $8.9 \mathrm{kPa}$ (range $5 \cdot 5-16$ ). Almost $40 \%$ of the patients had values of $\mathrm{PaO}_{2}$ lower than $8 \mathrm{kPa}$. Nineteen patients required mechanical ventilation. The haematological and biochemical 
Table 3 Prognostic factors of Pneumocystis carinii pneumonia in patients with AIDS: univariate analysis

\begin{tabular}{|c|c|c|c|}
\hline Variable & No. died/total (\%) & Odds ratio $(95 \%$ CI) & $p$ value \\
\hline $\begin{array}{l}\text { Sex } \\
\text { Female } \\
\text { Male }\end{array}$ & $\begin{array}{c}0 / 7 \quad(0 \%) \\
29 / 95(30 \%)\end{array}$ & $6.65(0.37$ to $1 \cdot 17)$ & NS \\
\hline $\begin{array}{l}\text { Age } \\
<35 \text { years } \\
>35 \text { years }\end{array}$ & $\begin{array}{l}16 / 71(22 \%) \\
13 / 31(42 \%)\end{array}$ & $2.48(0.91$ to 6.77$)$ & NS \\
\hline $\begin{array}{l}\text { Risk group } \\
\text { Drug abuser } \\
\text { Non-drug abuser }\end{array}$ & $\begin{array}{r}7 / 51(14 \%) \\
22 / 51(43 \%)\end{array}$ & $4.77(1.65$ to $14 \cdot 21)$ & $<0.001$ \\
\hline $\begin{array}{l}\text { AIDS diagnosis } \\
1988-9 \\
1985-7\end{array}$ & $\begin{array}{l}12 / 62(19 \%) \\
17 / 40(43 \%)\end{array}$ & $3.08(1.16$ to $8 \cdot 26)$ & $<0.05$ \\
\hline $\begin{array}{l}\text { Symptoms before admission } \\
<28 \text { days } \\
>28 \text { days }\end{array}$ & $\begin{array}{l}18 / 73(25 \%) \\
11 / 29(38 \%)\end{array}$ & $1.87(0.67$ to $5 \cdot 16)$ & NS \\
\hline $\begin{array}{l}\mathrm{PaO}_{2} \text { on admission } \\
\quad>8 \mathrm{kPa} \\
<8 \mathrm{kPa}\end{array}$ & $\begin{array}{l}11 / 62(18 \%) \\
18 / 40(45 \%)\end{array}$ & $3.79(1.41$ to 10.35$)$ & $<0.01$ \\
\hline $\begin{array}{l}\text { ARF } \\
\text { Absent } \\
\text { Present }\end{array}$ & $\begin{array}{cl}22 / 95 & (23 \%) \\
7 / 7 & (100 \%)\end{array}$ & $49.00(6.98$ to 343$)$ & $<0.001$ \\
\hline $\begin{array}{l}\text { Mechanical ventilation } \\
\text { Absent } \\
\text { Present }\end{array}$ & $\begin{array}{l}14 / 83(17 \%) \\
15 / 19(79 \%)\end{array}$ & $18 \cdot 50(4.76$ to $84 \cdot 67)$ & $<0.001$ \\
\hline $\begin{array}{l}\text { Therapy } \\
\text { TMT/SMX } \\
\text { No TMT/SMX }\end{array}$ & $\begin{array}{l}10 / 72(14 \%) \\
19 / 30(63 \%)\end{array}$ & $10 \cdot 71(3.56$ to $33 \cdot 30)$ & $<0.001$ \\
\hline $\begin{array}{l}\text { AIDS indicator event } \\
\text { Kaposi's sarcoma and other } \\
\text { PCP }\end{array}$ & $\begin{array}{r}8 / 38(21 \%) \\
21 / 64(33 \%)\end{array}$ & $1.83(0.66$ to 5.22$)$ & NS \\
\hline $\begin{array}{l}\text { Chest radiography } \\
\text { Severe abnormal } \\
\text { Normal/mildly abnormal }\end{array}$ & $\begin{array}{l}15 / 63(24 \%) \\
12 / 37(32 \%)\end{array}$ & $1.54(0.57$ to $4 \cdot 15)$ & NS \\
\hline $\begin{array}{l}\text { Multiple microbial infections } \\
\text { Absent } \\
\text { Present }\end{array}$ & $\begin{array}{l}19 / 86(22 \%) \\
10 / 16(62 \%)\end{array}$ & $5.88(1.68$ to 21.29$)$ & $<0.005$ \\
\hline $\begin{array}{l}\mathrm{LDH} \\
<22.5 \mu \mathrm{kat} / 1 \\
>22.5 \mu \mathrm{kat} / 1\end{array}$ & $\begin{array}{l}15 / 75(20 \%) \\
11 / 17(65 \%)\end{array}$ & $7.33(2.06$ to $27 \cdot 12)$ & $<0.001$ \\
\hline $\begin{array}{l}\text { Albumin } \\
>30 \mathrm{~g} / 1 \\
<30 \mathrm{~g} / 1\end{array}$ & $\begin{array}{r}7 / 54(13 \%) \\
21 / 43(49 \%)\end{array}$ & $6 \cdot 41(2 \cdot 16$ to $19 \cdot 68)$ & $<0.001$ \\
\hline $\begin{array}{l}\text { Leucocytes } \\
\quad<4.5 \times 10^{9} / 1 \\
>4.5 \times 10^{9} / 1\end{array}$ & $\begin{array}{r}8 / 42(19 \%) \\
21 / 60(35 \%)\end{array}$ & $2.29(0.82$ to 6.59$)$ & NS \\
\hline $\begin{array}{l}\text { CD4 + lymphocytes } \\
>0.1 \times 10^{9} / 1 \\
<0.1 \times 10^{9} / 1\end{array}$ & $\begin{array}{l}4 / 23(17 \%) \\
7 / 26(27 \%)\end{array}$ & $1.75(0.37$ to $8 \cdot 70)$ & NS \\
\hline $\begin{array}{l}\text { Haemoglobin } \\
\quad<100 \mathrm{~g} / 1 \\
>100 \mathrm{~g} / 1\end{array}$ & $\begin{array}{r}8 / 38(21 \%) \\
20 / 64(31 \%)\end{array}$ & $1 \cdot 70(0.61$ to $4 \cdot 88)$ & NS \\
\hline $\begin{array}{l}\text { Cholesterol } \\
>3.1 \mathrm{mmol} / 1 \\
<3.1 \mathrm{mmol} / 1\end{array}$ & $\begin{array}{l}14 / 62(23 \%) \\
13 / 33(39 \%)\end{array}$ & $2 \cdot 23(0.81$ to $6 \cdot 17)$ & NS \\
\hline
\end{tabular}

All blood analysis were performed on admission.

$\mathrm{ARF}=$ severe acute respiratory failure; TMT/SMX = trimethoprim-sulphamethoxazole; $\mathrm{LDH}=$ lactate dehydrogenase. odds ratios and statistical significance levels are summarised in table 3 . The univariate analysis for prognosis showed the following 10 factors to be related to a poor outcome: age $>35$ years; risk factor for HIV infection other than drug abuse; diagnosis of AIDS made before 1987; $\mathrm{PaO}_{2}<8 \mathrm{kPa}$ at admission; severe acute respiratory failure on admission; the need for mechanical ventilation; antibiotic treatment for PCP other than trimethoprim-sulphamethoxazole; multiple pulmonary microbial infection; serum $\mathrm{LDH}>22.5 \mu \mathrm{kat} / 1$; and serum albumin $<30 \mathrm{~g} / \mathrm{l}$. The following variables were not associated with a poor prognosis: indicator event of AIDS; duration of the symptoms before admission; chest radiographic characteristics; leucocyte count, CD4 lymphocyte count; and haemoglobin and cholesterol levels.

The multivariate analysis demonstrated that only one significant variable from the univariate analysis was independently associated with a worse prognosis - namely, mechanical ventilation requirement $(p<0.0002)$. The serum level of $\mathrm{LDH}>22.5 \mu \mathrm{kat} / 1 \quad(\mathrm{p}=0.07)$ and antibiotic treatment for PCP other than trimethoprim-sulphamethoxazole $(p=0.056)$ almost reached statistical significance. Table 4 shows the results of this multivariate analysis.

\section{Discussion}

The main finding of the present study was that mechanical ventilation requirement was the only factor independently related to a poor outcome in a multivariate analysis in patients with AIDS presenting with a first episode of PCP before 1990 .

The crude mortality of our patients was $28 \%$, which is similar to other publications ${ }^{1461322}$ for PCP in patients with AIDS, although in these studies the percentage mortality depended on whether it was the first or second episode of PCP. ${ }^{623}$ In patients presenting with severe acute respiratory failure mortality was higher than the overall mortality and is consistent with previous reports. ${ }^{711}$ However, the mortality ratio of PCP is falling over time to less than $5 \%$ for mild episodes and to about $20 \%$ for severe episodes. ${ }^{26}$ In fact, the mortality ratio in our earlier patients (1985-7) was $43 \%$, but in the most recent cases (1988-9) it was only $19 \%$, probably due to improved experience and the introduction of corticosteroids. ${ }^{2627}$

Four studies have investigated prognostic factors of PCP in patients with AIDS using univariate techniques. Overall these studies showed that clinical severity at admission (measured by APACHE II score), severe respiratory failure, serious radiographic abnormalities, extent of malnutrition and the level of serum $\mathrm{LDH}$ were the main factors related to poor prognosis. ${ }^{367}$ In addition, the severity of interstitial pulmonary oedema seen on transbronchial biopsy and more than 5\% neutrophils in bronchoalveolar fluid samples were also associated with a poor prognosis. ${ }^{12}$

Few studies for assessing the prognosis of PCP have used a statistical multivariate approach. The APACHE II score and the serum $\mathrm{LDH}$ level on admission were the only variables multivariate analysis

\begin{tabular}{llcl}
\hline Variable & High risk & Odds ratio $(95 \%$ CI) & p value \\
\hline Mechanical ventilation & Present & $68.96(7.70$ to 621.54$)$ & $<0.0002$ \\
PCP therapy & No TMT/SMX & $4.08(0.98$ to 16.39$)$ & NS \\
Serum LDH & $>22.5 \mu \mathrm{kat} / \mathrm{l}$ & $3.39(0.80$ to 14.28$)$ & NS
\end{tabular}

The variables used for the multivariate analysis were age, HIV risk factor, year of AIDS diagnosis, $\mathrm{PaO}_{2}$ on admission, mechanical ventilation, type of PCP therapy, presence of a pulmonary polymicrobial infection, serum LDH level, and serum albumin level.

TMT/SMX = trimethoprim-sulphamethoxazole; $\mathrm{LDH}=$ lactate dehydrogenase 
related to prognosis in one study. ${ }^{3}$ Another found that severe chest radiographic abnormalities and an $\mathrm{A}-\mathrm{a} \mathrm{Po}_{2}$ of $>4 \mathrm{kPa}$ on admission were indicators of poor prognosis during treatment for acute episodes of PCP. ${ }^{6}$ In our study the requirement for mechanical ventilation was the only variable independently related to a poor outcome.

Serum LDH levels are increased in $\mathrm{PCP}^{4}$ and may be a good marker of interstitial pulmonary inflammation. We found that a high level of lung inflammation was related to a poor prognosis, and a progressive decrease of $\mathrm{LDH}$ during treatment indicated response to treatment. ${ }^{4}$

Patients treated with pentamidine or pentamidine plus trimethoprim-sulphamethoxazole had a higher rate of mortality. This reflects a possible selection bias as initial treatment in most cases was trimethoprim-sulphamethoxazole. Treatment was changed to pentamidine in patients not doing well or if allergic reactions occurred.

Supported in part by "Fondo de Investigaciones Sanitarias de la Seguridad Social" (FIS\#92/0415 and FIS\#93/0164) and "Fundación Máximo Soriano Jimenez". Drs P Fernandez and $R$ Riquelme were fellows from Instituto Nacional de Enfermedades Respiratorias y Cirugia Toracica (Santiago de Chile, Chile) and from Hospital Base (Puerto Montt, Chile), respectively.

1 Murray JF, Garay SM, Hopewell PC, Mills J, Snider GL, Stover DE. Pulmonary complications of the acquired
immunodeficiency syndrome. Report of a National Heart, immunodeficiency syndrome. Report of a National Heart, Lung, and B

2 Hopewell PC. Pneumocystis carinii: diagnosis. F Infect Dis 1988;157:1115-9.

3 Benson AB, Spear J, Hines D, Pottage JC, Kessler HA, Trenholme GM. Combined APACHE II score and serum lactate dehydrogenase as predictors of in-hospital mortality caused by first episode Pneumocystis carinii pneumonia in patients with acquired immunodeficiency syndrome. $\mathrm{Am}$ Rev Respir Dis 1991;144:319-23.

4 Garay SM, Greene J. Prognostic indicators in the initial presentation of Pneumocystis carinii pneumonia. Chest presentation of

5 Stover DE, White DA, Romano PA, Gellene RA, Robeson WA. Spectrum of pulmonary diseases associated with the acquired immunodeficiency syndrome. Am $\mathcal{F}$ Med 1985; 78:429-37.

6 Brenner M, Ognibene FP, Lack E, Simmons JT, Suffredini AF, Lane HC, et al. Diagnostic factors and life expectancy of patients with acquired immunodeficiency syndrome and Pneumocystis carinii pneumonia. Am Rev Respir Dis 1987;136:1199-206.

7 Friedman Y, Franklin C, Rackow EC, Weil MH. Improved survival in patients with AIDS, Pneumocystis carinii pneumonia, and severe respiratory failure. Chest 1989;96:862-6.
8 Montaner JS, Russell JA, Lawson L, Ruedy J. Acute respiratory failure secondary to Pneumocystis carinii pneumonia in the acquired immunodeficiency syndrome. Chest 1989;95:881-4.

9 El-Sadr W, Simberkoff MS. Survival and prognostic factors in severe Pneumocystis carinii pneumonia requiring mechanical ventilation. Am Rev Respir Dis 1988;137:1264-7.

10 Peruzzi WT, Skoutelis A, Shapiro BA, Murphy RM, Currie $\mathrm{DL}$, Cane RD, et al. Intensive care unit patients with acquired immunodeficiency syndrome and Pneumocystis carinii pneumonia: suggested predictors of hospital outcarinii pneumonia: suggested predictors
come. Crit Care Med 1991;19:892-900.

11 Efferen LS, Nadarajah D, Palat DS. Survival following mechanical ventilation for Pneumocystis carinii pneumonia in patients with the acquired immunodeficiency syndrome: a different perspective. $A m \mathcal{F} M e d$ 1989;87:401-4.

12 Sadaghdar H, Huang $Z$, Eden E. Correlation of bronchoalveolar lavage findings to severity of Pneumocystis carinii pneumonia in AIDS. Chest 1992;102:63-9.

13 Wachter RM, Russi MB, Bloch DA, Hopewell PC, Luce JM. Pneumocystis carinii pneumonia and respiratory failure in AIDS. Am Rev Respir Dis 1991;143:251-6.

14 Centers For Disease Control. Revision of the CDC surveillance case definition for acquired immunodeficiency veillance case definition for acquired immunodefic
syndrome. $M M W R$ 1987;36(Suppl 1S): 3S-14S.

15 Murray JF, Matthay MA, Luce JM, Flick MR. An expanded definition of the adult respiratory distress syndrome. $\mathrm{Am}$ Rev Respir Dis 1988;138:720-3.

16 Shapiro BA, Harrison RA, Walton JR. Clinical application of blood gases. Chicago: Year Book Medical Publishers, 1987.

17 Mallolas J, Zamora L, Gatell JM, Miró JM, Vernet E, Valls ME, et al. Primary prophylaxis for Pneumocystis carinii pneumonia: a randomized trial comparing cotrimoxazole, aerosolized pentamidine and dapsone plus pyrimethamine. AIDS 1993;7:59-64.

18 Schlesselman JJ. Case control studies. 1st edn. New York: Oxford University Press, 1982

19 Cox DR. Analysis of binary data. 1st edn. London: Methuen and Co, 1970.

20 Lee ET. Statistical methods for survival data analysis. 1st edn. Belmont, California: Lifetime Learning Publications, 1980.

21 Breslow NE, Day NE. Statistical methods in cancer research, Vol 1. The analysis of case-control studies. Lyon: International Agency for Research on Cancer, 1980

22 Kovacs JA, Hiemenz JW, Macher AM, Stover D, Murray HW, Shelhamer J, et al. Pneumocystis carinii pneumonia: a comparison between patients with the acquired ima comparison between patients with the acquired im-
munodeficiency syndrome and with other immunomunodeficiency syndrome and with other
deficiencies. Ann Intern Med 1984;100:663-71.

23 Dohn MN, Baughman RP, Vigdorth EM, Frame DL. Equal survival rates for first, second, and third episodes of Pneumocystis carinii pneumonia in patients with acquired immunodeficiency syndrome. Arch Intern Med 1992;152: 2465-70.

24 Wharton JM, Coleman DL, Wofsy CB, Luce JM, Blumenfeld W, Hadley WK, et al. Trimethoprim-sulphamethoxazole or pentamidine for Pneumocystis carinii methoxazole or pentamidine for Pneumocystis carini pneumonia in the acquired immunor

25 Kovacs JA, Masur H. Pneumocystis carinii pneumonia: and prophylaxis. F Infect Dis 1988;158:254-9.

26 Bozzette SA, Sattler FR, Chiu J, Wu AW, Gluckstein D, Kemper C, et al. A controlled trial of early adjuntive treatment with corticosteroids for Pneumocystis carinii pneumonia in the acquired immunodeficiency syndrome. N Engl f Med 1990;323:1451-7.

27 LaRocco A, Amundson DE, Wallace MR, Malone JR, Oldfield EC. Corticosteroids for Pneumocystis carinii pneumonia with acute respiratory failure. Chest 1992;102: pneumo 